Euskal ikerketen aldizkaria | Revue d'études basques |

Revista de estudios vascos | Basque studies review

$13 \mid 2009$

Numéro XIII

\title{
Aldaera sintaktikoak aditzaren fokalizazioan
}

\section{Arantzazu Elordieta}

\section{OpenEdition}

\section{Journals}

Édition électronique

URL : http://journals.openedition.org/lapurdum/2018

DOI : 10.4000/lapurdum.2018

ISSN : 1965-0655

Éditeur

IKER

Édition imprimée

Date de publication : 1 février 2009

Pagination : 99-112

ISBN : 978-2-86781-409-X

ISSN : $1273-3830$

\section{Référence électronique}

Arantzazu Elordieta, « Aldaera sintaktikoak aditzaren fokalizazioan », Lapurdum [Linean], 13|2009,

Sarean emana---an 15 avril 2013, kontsultatu 30 avril 2019. URL : http://journals.openedition.org/ lapurdum/2018 ; DOI : 10.4000/lapurdum.2018 


\title{
Aldaera sintaktikoak aditzaren fokalizazioan
}

\author{
Arantzazu Elordieta \\ UPV/EHU
}

\begin{abstract}
:
In this article we will discuss two syntactic mechanisms that only certain Basque dialects display in V-focalization contexts: (1) synthetic V-doubling and (2) insertion of dummy $V$ egin. On the other hand, instances of dummy egin in contexts other than $V$-focalization, such as $V(P)$-topicalization, will also be considered, given the interesting fact that in such structures the use of egin is general across dialects, contrary to what occurs when $V$ is focalized. Drawing from this difference, I will present an approach which seeks to shed some light on the reasons for the dialectal distribution of dummy egin and V-doubling in Basque.
\end{abstract}

\section{Laburpena:}

Lan honetan aditza fokalizatu nahi dugunean euskararen zenbait aldaerak erakusten dituzten bi estrategia sintaktiko aztertuko ditugu: (1) aditz (trinko)aren bikoizketa eta (2) egin aditz betegarriaren txertatzea. Bestetik, egin fokalizazio egituretatik kanpo erabiltzen den beste testuinguru bat izango dugu hizpide: aditz (sintagma)ren topikalizazioa hain zuzen. Aditzaren fokalizazioan gertatzen ez den bezala, euskalkietan zehar egin-en erabilera hedatuagoa da topikalizazio egituretan. Bereizketa honetatik abiatuz, egin-en eta aditzaren bikoizketaren banaketa dialektalerako hurbilketa bat aurkeztuko dut.

Gako-hitzak: aditzaren fokalizazioa, aditz-bikoizketa, egin betegarria

Keywords: verb focalization, verb doubling, dummy egin.

\section{Sarrera gisa ${ }^{1}$}

Lehenik eta behin, lan honetan 'aditzaren fokalizazioa'z dihardudanean zertaz ari naizen zehaztuko dut, sarri asko deitura horren azpian adierazpide bat baino gehiago ezkutatzen ohi baita.

1. Artikulu honek Baionan 2008ko abenduaren 13-14ean Aldaketak, aldaerak, bariazioak euskaran eta euskal testugintzan Nazioarteko Mintegia-ren barruan eman nuen hitzaldian du oinarria. Eskerrak eman nahi dizkiet biltzarreko antolatzaileei eta parte hartzaileei emandako harrera on eta iruzkinengatik. Bereziki eskerrak eman nahi dizkiot Milan Rezac-i, aditz bikoizketari buruzko lan batzuen berri emateagatik, eta Xabier Artiagoitia eta Gorka Elordietari idatzizko bertsioaren gainean egindako ohar eta iruzkinengatik. Lan hau zenbait ikerketa proiekturen babesean burutu da: EHUko EHU07/13 ikerketa proiektua, Espainiako Zientzia eta Berrikuntzako Ministeritzaren FFI2008-05135/FILO ikerketa proiektua, bai eta Eusko Jaurlaritzak IT-210-107 ikerketa taldeari eta HM-2008-1-10 ikerketa sareari emandako laguntzari esker. 
Neurri batean, (1)-(4) perpausak denak har daitezke aditzaren fokalizazioaren adibidetzat, baina egiatan ez dira baliokideak, zenbait euskalkitan behintzat:

(1) badatoz geurera azkenean be

(2) bizikleta apurtua konpondu egingo dute, merezi duelakoan

(3) gainditu du oso txarto egin omen zuen azterketa

(4) jakin daki arek gai horren eta beste askoren gainean

Izan ere, hainbat hiztunen arabera, (1) eta (3)-ko egituretan esaldiaren baiezkotasuna ageri da nabarmenduta; aitzitik, (2) eta (4)-ko adibideetan, aditzak adierazten duen ekintza edo gertaera bera da fokua. Bereizketa hau ez da, nolanahi ere, orokorra euskaraz: hizkera batzuetan egin ez da erabiltzen aditzaren fokalizaziorako, eta jakin daki tankerako bikoizketen erabilera-eremua are murritzagoa da, ondoren zehaztuko denez.

\section{Datuak: 1. bariazioa}

Aztertuko dugun euskalkien arteko lehen aldakortasuna egin aditz betegarri edo arinaren erabilerari dagokio. Zuazoren (2003: 186) hitzak hona ekarriz, egin indargarri gisa erabiltzeko ezaugarria "mendebala eta erdialdea alde batera, eta ekialdea bestera jartzen dituen bereizgarri bat" da. ${ }^{2}$ Izan ere, aditzaren ekintza edo gertaera fokalizatzeko egin erabiltzen dute mendebaleko eta erdialdeko euskalkiek eta Sakana eta Malerrekako 'tarteko' hizkerek (cf. Zuazo 1998: 221, 2003: 186); baina beste hizkeretan ez dute egin erabiltzen xede horretarako (ikus baita Zuazo 2008:216). Hizkera hauetan guztietan fokua aditzaren ekintza den ala baieztapena/ezeztapena den ongi bereizten dute (bereizketa honetaz, ikus Altube 1929, Arejita 1980, 1984, Euskaltzaindia 1985, Ortiz de Urbina 1989, Osa 1990, Etxepare \& Ortiz de Urbina 2003):

(5) a. Erosi du Naiak liburua (fokua=baieztapena, polaritate-fokua)

b. Erosi egin du Naiak liburua (fokua=ekintza) ${ }^{3}$

Bestetik, aditza fokalizatzeko estrategia hau erabiltzen ez den beste hizkeretan badirudi bereizketa -hau da, enfasia ekintzan bertan ala perpausaren egiatasun-balioan dagoen- ez dela markatzen, morfosintaktikoki, behintzat. Aitzitik, (5a) egiturak bi irakurketak adieraz ditzake, eta, hortaz, anbiguoa da foku-egituraz den bezainbatean (ikus Rebuschi 1983, Oyharçabal 1984, besteak beste).

\section{Datuak: 2. bariazioa}

Aditzaren fokalizazioan aurkitzen dugun aldakortasunaren bigarren aztergaia aditzaren bikoiz-

2. Zuazoren proposamenean 'mendebaleko' euskararen eremua Bizkaia, Gipuzkoako Deba ibarra eta Arabako Aramaio eta Legutio da, eta 'erdialdeko' hizkerak Gipuzkoako gehienak eta Nafarroako sartaldekoak, hots, Basaburuko haranekoak (salbu Goizueta eta Beintza-Labaien), Araitz, Imotz (Muskitz izan ezik) eta Larraunekoak (Zuazo 1998: 218, 2008: 61).

3. Esan behar da (5b)-n aztertzen ari garen foku mota foku estua dela beti (narrow focus), baina informatiboa edo kontrastiboa izan daiteke, testuinguruaren arabera. Esaterako, (5b) bi testuinguru hauetan erabil daiteke:

(i) Zer egin du Naiak liburuarekin? Erantzuna: (5b) (informatiboa)

(ii) Erosi egin du Naiak liburua, ez du maileguan hartu (kontrastiboa). 
keta da. Fokalizazio-estrategia honen banaketa dialektala mugatuagoa dela dirudi, zeren bizkaieraren - edo, Zuazoren $(1998,2003,2998)$ sisteman, mendebalaren- ezaugarritzat jo izan bada ere (ikus Altube 1929, Mitxelena 1981, Arejita 1984, Euskaltzaindia 1985: 48, Zuazo 1998: 207-208, Zuazo 2008: 81-82, Etxepare \& Ortiz de Urbina 2003: 355), aipagarria da egin-en aldean erabilera txikiagoa duela bizkaieran bertan, bai maiztasunean bai hedaduran. ${ }^{4}$ Fokalizazio mota honek aditz trinkoei bakarrik eragiten die: aditzok adierazten duten ekintza fokalizatu nahi denean, aditza errepikatu egiten da, lehendabizi forma ez jokatuan, eta gero adizki trinko eran:

(6) a. Juen doie, ala etorri dator, ba? (Mallabia, Bizkaia. Zuazo 1998: 207)

b. euri sein aterri, yon gos [joan goaz] (Urduliz, Bizkaia. Zuazo 2008:81)

Adizki trinkoen kopurua berez mugatua izateak ukaezineko eragina du erabileraren maiztasunean, adibideak gutxiago eta nekezago aurkituko ditugulako. Horri gehitzen badiogu egiturok oso kontestu zehatzetan erabiltzen direla, ez da harritzekoa bikoizketa egitura hauek erabilera mugatua erakustea. $^{5}$

Bestalde, estrategia hau erabiltzen ez duten hizkeretan, polaritate-fokuaren eta ekintza-fokuaren arteko bereizketa galdu egiten da aditz trinkoekin. Badirudi horrelakoetan ba- partikula eransten zaiola adizki trinkoari (Euskaltzaindia 1985:47, Etxepare \& Ortiz de Urbina 2003: 355):6

\section{(7) Bazatoz ala bazoaz?}

\section{Aldakortasunaz hausnartzen}

Aditzaren fokalizazioaren barneko bereizketa honen aurrean -hots, fokua ekintza ala baieztapena bera den- hainbat galdera sortzen zaizkigu: batetik, bereizketa berrikuntza den ala aspaldiko joera orokor baten aztarna den galde diezaiokegu gure buruari. Iturri bibliografikoetan begiratuta, egin indargarriaren lehen lekukotasunak bizkaierazko idazleengan aurkitzen dira, XVI. mende bukaeran jada, eta gipuzkerazko testuetan XIX. mendera arte ez da aurkitzen erabilera hau. Mitxelenak dioenez, XX. mendean ugaldu egiten da aurreko aditzaren indargarri gisara: "para marcar el carácter focal del verbo precedente o como intensivo del verbo precedente" (OEH: VI: 416), goi-nafarrerako eta zenbait ekialdeko idazleren testuetara ere hedatuz (cf. ibid., Arejita 1980). Beraz, badirudi bizkaieraz aspaldian erabili izan den egitura dela, baina ez da hala gertatzen beste

4. Osak (1990:168) dioenari kasu egiten badiogu, aditz itzuli hauek gaur egun arruntak dira Bizkaiaz kanpo Deba arroan ere, Legazpiraino iristen direlarik, eta bestalde, hizketan usuagoak dira idazterakoan baino. Beharbada horregatik ez da ia lekukotasunik aurkitzen testu idatzietan. Era berean, Zuazok (2008:81-82) dakartzan lekukotasunak Urdulizen jasoak dira, baina egitura hauek mendebal gehienera hedatzen direla ohartarazten du.

5. Eskerrak eman nahi dizkiot Koldo Zuazori egitura hauen gainean ohar batzuk egiteagatik.

6. Mitxelenak (1981:76) ohartarazten du kasu bakan batzuetan irtenbide bat edo beste ematen zaiola aditzaren ekintza fokalizatu nahi izateari: alde batetik, egonean nago, ibilian nabil tankerakoen bidez, eta bestetik, ari+IZAN aditz itzuliaren bidez:

(i) A. Ekarri ala eraman egiten duzu?

B. ekartzen ari naiz (=ekarri dakart, gutxi gorabehera). 
euskalkietan, hauetan erabilera berriagoa delarik. ${ }^{78}$ Ibili dabil egituren lekukotasunak urriagoak dira, goian aipatu denez, baina dauden zaharrenak bizkaieraren eremukoak dira, eta hauek XIX. mendera arte ez dira aurkitzen. ${ }^{9}$

Bestetik, mendebalean dakusagun bereizketa morfosintaktikoak bereizketa semantikoa adierazten du. Hala bada, batek esperoko luke eragin semantikoa duen bereizketa hori beste hizkeretan ere nolabait islatzea, dela beste mekanismoren bidez, dela bereizketa egiten duen euskalkiaren egitura orokortzearen bidez. Egin-en kasuan, badirudi hala gertatu dela, ekialdeko hizkeretan izan ezik. Baina hauetan perpauseko osagaiak fokalizatzeko mekanismo berezi baten bidez balia daitezke, eta agian horregatik ez dugu egin aurkitzen. Izan ere, Lafittek (1944) eta bestek ohartarazi duten bezala, ekialdeko hizkeretan fokua aditz jokatuaren aurrean agertzen da, osagai hori edozein delarik, aditz lexikoa barne. ${ }^{10}$ Hala, ondoko adibideetan aditz laguntzailearen aurreko sintagma (8a) nahiz aditza bera dira fokuak:

(8) a. Piarres da hil (C'est Pierre qui est mort)

b. Hil da Piarres (Il est mort, Pierre)

[Lafitte 1978: 47]

Aditzaren fokalizazioaren inguruko aldaera sintaktikoak zein diren aurkeztu ondoren, ondorengo ataletan egin-en eta joan doa tankerako egitura sintaktikoak aztertzeko bideak jorratuko ditut.

\section{Egin egiturak}

\subsection{Rebuschi (1983)}

Goian aipatu dugunez, mendebaleko eta erdialdeko euskalkietan egin aditz arina edo betegarria txertatzen da aditz nagusiarekin batera aditzak adierazten duen ekintza edo gertaera fokalizatu nahi dugunean, (9)-n ikus daitekeen moduan:

(9) a. Andoni Azpiazu absolbitu egin du Espainiako Auzitegi Nazionalak

b. Eraikinaren oinarriak indartzea ere lan handia izango da. Egurrezko pilote batzuk baitira, eta indartu egin behar dira

[Berria 2008-01-21]

Rebuschik (1983b) azterbide sintaktiko aitzindaria proposatu zuen egin aditz betegarriaren agerpena azaltzeko. Euskaraz osagai fokalizatuak perpaus hasierako foku gune batera mugitzen

7. Izan ere, Celine Mounolek (2008) proposatzen duenez, oso litekeena da egin aditzarekin osatutako perifrasien sorrera fokuarekin izatea zerikusia: bere ustez, bizkaieraz egin aditz laguntzailea aditz partizipioa fokalizatzeko hasi zen erabiltzen, eta denborarekin, beste euskalkietara hedatu ondoren jatorrizko adiera fokalizatzailea gal zezakeen, laguntzaile iragankorraren funtzioa bereganatuz.

8. Bestela iritzi dio Zuazok (2008:216), mendebaleko eta erdialdeko ezaugarria den hau berrikuntzatzat baitauka.

9. Peru Abarka-n (1802, 188lean argitaratua) horrelako forma batzuk ageri dira (entzun dantzu), baina Mitxelenak (1981:75) zioenez, ez dira asko agertzen testu zaharretan.

10. Hegoaldeko euskalkietako eredua ere erabiltzen da, hots, fokua+aditz lexikoa+aditz laguntzailea, baina alderantzizkatutako egiturak nolabait nabarmendu egiten du zein den fokua perpausean (cf. Lafitte 1978:48, Irurtzun eta Duguine 2008). 
direla onartuz -esaterako, FokuS-ra-, Rebuschik proposatzen du bizkaieraz eta gipuzkeraz aditz partizipioa fokua denean eragiketa bera gertatzen dela, moldaketa txiki batekin. Hau da, aditza perpaus hasieran kokatzen da, 'foku posizioan', baina ez mugimenduaren ondorioz, baizik eta kopiatu egin delako. Kopiaren aldeko arrazoi nagusia aditz topikalizazioetan aurkitzen ditugun erosi, gehiegi erosten dugu guk, beharrik gabe moduko adibideetan dago: Rebuschiren ustez, horietan aditza bi aldiz errepikatuta agertzen delarik, eta gainera, morfologikoki bi aditz formak guztiz berdinak izan gabe, zail samarra litzateke egiturok mugimenduaren bidez azaltzea. Jakina, argudio honen balioa garai hartan onartzen zen teoriaren barruan ulertu behar da, hots, mugimenduak sortutako katearen begia (edo burua) bakarrik 'entzuten' edo 'ahoskatzen' dela. Aldiz, gaur egun teoria sintaktikoan 'mugimendua' beste era batean ulertzeko proposamenak daude, nagusiki 'kopiatu eta ezabatu' eragiketen bidez. Hartara, gaur egun ez dagoke diferentzia handirik proposatzean X/XS gune batera mugitu dela edo gune batera kopiatu dela.

Rebuschiren proposamena (10)-en dakargu laburtuta: horren arabera, aditz partizipioa Foku Sintagman kopiatu da, eta horren ondorioz jatorrizko gunean egin aditz betegarriarekin ordezkatzen da, aspektu-tasunak baliozta ditzan: ${ }^{11}$

$$
\left[_ { \text { FokS } } \text { A... } \left[_{\text {InflS }}[\text { AS egin-Asp ] Infl]] }\right.\right.
$$

Analisi hau ontzat jo dute ondorengo lan gehienetan (ikus, nagusiki, Ortiz de Urbina 1995, Haddican 2005, 2007), intuitiboki bederen, baina azterbide honetan hainbat xehetasun geratzen dira zehazteke, hainbatek ohartarazi dutenez: batetik, zergatik ez da aditza aurreratzen aspektutasun eta guzti?

(11) *apurtuko egin(go) diozu kristala gogor jotzen baduzu

Bestetik, aditza fokalizatzean 'kopiatzea' gertatzen baldin bada, zergatik ez dira bi kopiak erabat berdinak morfologikoki?

(12) *apurtu apurtu diozu kristala eman diozun kolpearekin

Bestalde, Landauren (2006) argudioei jarraituz, hirugarren galdera bat ere egin daiteke, alegia, zergatik ahoskatzen diren elementu beraren bi kopiak, eta ez bakarra, ohikoa denez mugimendua gertatzen denean. ${ }^{12}$

11. Zentzu batean egin aditz betegarriaren txertaketak ingelesezko do-support-arekin du antza, Rebuschi bera (1983a) ohartu zenez. Do-support Denborak eta Aditzak bat egin ezin dutenean txertatzen da oro har, tartean beste kategoria batzuek oztopatzen dutelako mugimendua (ezeztapena, subjektua ez diren NZ-galderak, polaritate fokua, AS-ren topikalizazioa, AS-ren elipsia, ...). Bestalde, do bezala, egin aditza lexikoki hutsa edo betegarria da; izan ere, aditz nagusiarekin batera perpaus bakarra osatzen du, eta laguntzaile bakarraren hautaketa eta komunztadura aditz nagusiak zehazten du:

(i) gustatu egin zait esan duzuna.

12. Landauk hebraierazko kasua aztertzen du. Hizkuntza honetan A zein AS topikalizazio bidez aurreratzen direnean 'beheko' egongunean mugitutako elementuaren kopia bat uzten dute (ikus Landau 2006, 2007). 
Hain zuzen ere, lehen bi galderei erantzuten saiatuko da hurrengo atalera ekarriko dugun Haddicanen $(2005,2007)$ proposamena.

\subsection{Haddican $(2005,2007)$}

Haddicanek aditz fokalizazioetako egin egiturak ditu aztergai. Rebuschiren proposamenaren ideia nagusitik abiatuta, aditz lexikoa Foku Sintagmara mugitzen dela defenditzen du, baina aurreko analisia garatu eta hobetuz, azaltzen saiatzen da egin egituretako aditz fokalizatuak zergatik ezin duen aspektu markarik eraman. Laburki esateko, Haddicanek proposatzen du aditz fokalizatua ez dela partizipioa, baizik eta infinitibo nominalizatua, hots, izen kategoriakoa. Izena bada, edozein izenek bezala ezin du aspektu markarik jaso, eta, ondorioz, jatorrizko gunean egin aditz arina txertatzen da perpausa ongi eratuta egon dadin behar diren aspektu markak balioztatzeko. Ideia honen arabera, beraz, aditz fokalizatuak daraman -i/-tu/-n/-ø atzizkia ez da aspektu burutuaren marka, infinitibo marka baizik; zehatzago, [+izena] tasuna duen Infinitibo Sintagmaren burua da. ${ }^{13}$ Manfredik (1993) Haitiera kriolloa eta kru hizkuntzetako aditz fokalizazioak aztertu ondoren ateratzen duen orokorpena bereganatuz, Haddicanek proposatzen du fokalizatu nahi den osagai oro [+izen] izan behar dela. ${ }^{14}$ Hartara, aditza fokua denean, InfinS-ra mugitzen da, izen bihurtzeko, eta, ondoren, InfinS osoa FokuS-ren espezifikatzailera mugituko da [+fokua] tasuna zilegiztatzeko. ${ }^{15}$ Baina eratorketa honen bidez aspektu markak balioztatu gabe gelditzen dira. Hau saihesteko txertatzen da egin egituran: ${ }^{16}$

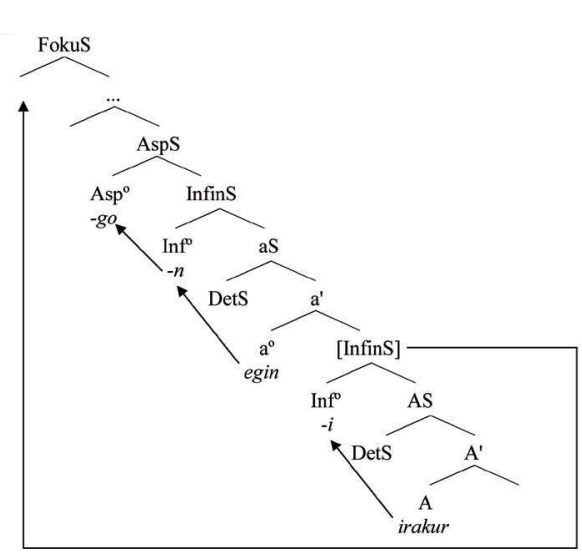

13. Aipatu beharra dago aurretik ere partizipioaren izaera bikoitz honetaz ohartu direla zenbait (cf. esaterako, Euskaltzaindia 1985, 1993, Artiagoitia 1995).

14. Haitieran eta kru hizkuntzetan ere aditza fokua denean marka nominalizatzailea eramaten du (cf. Manfredi 1993).

15. Haddicanen analisian mugimendu hauek sintagma-mugimenduak dira, ez buru-mugimenduak: lehenik, AS [Esp,InfinS]-ra mugitzen da, eta ondoren, InfinS [Esp, FokuS]-ra. Egia esan, bigarren mugimenduan FokuS-ren espezifikatzailera mugitzen dena InfinS baino osagai handiagoa da, NzS (WhP), baina lan honen mugetatik kanpo dago analisiaren argudio eta zehaztasun osoak hemen ematea. Interesa dutenak autorearen beraren lana irakurtzera gonbidatu nahi nituzke.

16. Haddicanek azterbide antisimetrikoa jarraitzen du euskararen perpaus egiturarako. Horrela, buru guztiak dira lehen (13)-ko irudikapen sintaktikoan. 
Analisi hau Rebuschirena baino landuagoa da, zalantzarik gabe, eta neurri handi batean azalgarriagoa ere bai, hark irekita uzten dituen zenbait galderari erantzuten saiatzen baita; hala ere, ene iduriz, galdera berriak ere sortzen ditu. Alde batetik, Haddicanen arabera, FokuS-ra mugitzen dena $\left[{ }_{\text {Infins }}\left[{ }_{A S}\right]-i_{[+i z]}\right] d a$, alegia, sintagma mugimendua da, ez buru mugimendua. Abiapuntu horretatik, azaldu behar dena fokalizatutako aditzaren eta egin-en arteko albokotasuna da. Beste modu batera esanda, aditz fokalizazioan sintagma-mugimendua bada, beheko InfinS FokuS-ren espezifikatzailera mugitu baino lehenago, AS barruko osagai guztiak AS-tik kanpo atera behar dira, horrelakoetan foku interpretazioa duen bakarra aditz nagusia baita, ez AS (ezta ere AS-tik gorako sintagmarik). DetS diren osagaien kasuan, AS-tik kanpo ateratzeko arrazoi nagusia kasu zilegiztapenarekin lotuta egon daiteke. ${ }^{17}$ Hain argi ez dagoena da -batik bat aintzat hartzen badugu Haddicanen proposamenean euskara buru-lehen dela- zergatik atera behar diren kasurik jasotzen ez duten beste osagaiak (PostS-ak eta adberbioak, esaterako), eta inora mugitzekotan, nora mugitzen diren. Hau ikusteko, erkatu (14a-b)-ko adibideak. (13)-ko irudikapenetik abiaturik, (14b) adibideak erakusten du parkean PostS-k ezin duela AS barruan gelditu; aitzitik, eratorpen zuzena izateko, seguru asko aS-ren eta AS-ren tarteko islapen batera mugitu da, baina mugimenduaren arrazoiak eta jomuga ez dira ezagunak:

(14) a. Umeek jolastu egiten dute parkean

b. *Umeek jolastu parkean egiten dute (fokua aditza den zentzuan)

Bigarrenik, analisi honen arabera edozein fokuk [+izen] izan behar duenez, ez dago argi zelan aztertu beharko liratekeen fokaliza daitezkeen adberbioak eta postposizio sintagmak. ${ }^{18}$ Hirugarren arazoak aditz topikalizazioetan aurkitzen den egin-en agerpenarekin du zerikusia. Izan ere, aditz fokalizazioaren kasuaz gain, aditza eta AS topikoak direnean euskalki eta hizkera guztietan erabil daiteke egin aditz betegarria, aukeran, aditzaren errepikapenarekin batera:

(15) a. esan, egin duzu, baina alferrik, inork ez dizu kasurik egingo eta ${ }^{19}$

b. esan esan duzu, baina alferrik, inork ez dizu kasurik egingo eta

Goiko adibideetan ikus dezakegunez, topikalizatutako aditzak ere fokalizatutakoak dituen aspektuzko murriztapen berak erakusten ditu. Haddicanek berak kontu honi begiratzen ez badio ere, pentsa dezakegu bere azterbidea erabilera honetara ere hedatu beharko litzatekeela, aditz sintagmaren jomuga gorabehera (kasu honetan TopS-ren espezifikatzailera mugituko bailitzateke, segur aski). Horrek, modu berean, berarekin ekarriko luke proposatzea [+izen] diren kategoriako elementuak soilik topikaliza daitezkeela, datuek erakusten dutenaren aurka, hain zuzen.

\section{Hasierako analisira itzuliz: aditza FokuS-ra mugitzen da}

Bada modurik fokalizazio egitura honen berri emateko Haddicanen analisiak erakusten dituen

17. Bidenabar, horrek esan nahiko luke kasua aS txikiaren eta beheko InfinS-ren tarteko islapen funtzional bat(zu)etan zilegiztatzen dela, aditza+egin hurrenkeraren berri eman nahi badugu.

18. Haddicanek berak ohartarazten du arazo honetaz.

19. Ohart bedi aditzaren ondoren etena dagoela. Etenik gabe aditza foku gisa ulertuko litzateke. 
arazoak saihestuz. Hain zuzen ere, aurkeztuko dudan proposamenak Rebuschiren intuizioa zuzena zela defendituko du. Hala, eman dezagun aditza fokua denean FokuS-ren espezifikatzailera mugitzen dela, gainerako osagaiek egiten duten bezala fokua direnean. Kontestu horretan aditzak daraman i/-tu/-n markak ez du aspektu burutua adierazten, Rebuschik berak eta beste hainbatek ohartarazi dutenez. Marka hori partizipioaren esanahia galdu duen aditzaren aipamen forma ihartua da. Izan ere, Mounolek (2008) ongi erakusten duenez euskarazko perifrasi zaharren garapen historikoari buruz egiten duen proposamenean, mendebaleko (bizkaierazko) egin aditz laguntzailearen lehen lekukotasunetatik aditz nagusia -i/-tu/-n markarekin agertzen da ia beti, garai berean gainerako euskalkietan *ezan laguntzailea aditz erroarekin erabiltzen zen bitartean. Mounolek proposatzen du egin laguntzailea aditza fokalizatzeko erabiltzen zela hasieran, aditz nagusia -i/-tu/-n markarekin agertzen zelarik beti, eta litekeena dela gero, erabilera fokalizatzailea ahulduz joan zelarik, aditz laguntzaile gisa erabiltzen hasi izana, eredu hori beste euskalkien paradigmetara hedatu zen arte.

Nahiz eta Mounolen lanak egin laguntzaile gisa soilik aztertzen duen, esanguratsua da beti agertzen dela -i-tu/-n markaren batekin, partizipio perfektuaren adiera galdu duen arren. Ez da harritzekoa, hortaz, inguru fokalizatzaileetan erabiltzen denean ere marka berekin agertzea. Kontua da -i/-tu/-n markek ez badute aspektua adierazten aditza+-tu/-i/-n foku gunera mugitzen denean, aditz itxurako beste zerbaitek adierazi beharko duela aspektua. Hain zuzen, egin aditz betegarriak. Horrela, egin txertatzen da Asp buruan, aditzaren proforma gisa, A-ren mugimenduaren ondorioz sintaktikoki zein semantikoki balioztatu gabe geratzen diren aspektu-tasunak gauzatzeko.

Hurrengo urratsean egin aditz laguntzaileari adjunktatzen zaio eta ondoren buru konplexu osoa Foku burura mugitzen da, (16)-ko irudikapenak erakusten duenez. ${ }^{20}$ Modu horretan fokuak foku tasuna balioztatzen du Foku ${ }^{\circ}$ buruan dagoen kategoriarekin, eta bestalde aditz lexikoaren eta egin aditzaren arteko albokotasunaren berri eman daiteke, modu errazean: ${ }^{21}$

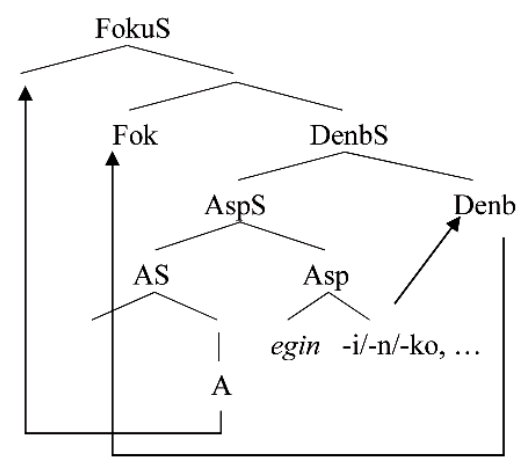

20. Aditz laguntzaileak euskaraz klitikoen jokabidea erakusten duela onartzen dut (ikus Ortiz de Urbina 1994 , 1995, Elordieta 2001), fonologikoki zein sintaktikoki, eta, horrenbestez, euskarri bat behar du zilegiztatua izateko. Ortiz de Urbinaren aburuz, zilegiztatzea buru batekin bat eginda lortzen du, dela aditza aditz laguntzailera mugituz, dela laguntzailea ezeztapenera mugituz (zehaztasun gehiago bilatzen duenak jo beza goian aipatutako lanetara). Egin egituretan aditz nagusiaren ordez egin betegarria mugitzen da inflexiora laguntzailea zilegiztatzeko, buru konplexua osatuz.

21. Aditz nagusiaren eta egin-en artean ezin da ezer tartekatu, ezeztapena izan ezik (ikus 9.4 atala). Horrek bestelako fokalizazioetan osagai fokalizatuaren eta aditz jokatuaren artean aurkitzen dugun A2 efektua dakarkigu gogora; gertakari beraren aurrean gaudela iduri du (cf. Ortiz de Urbina 1989 eta ondorengo lanak). 
Batek pentsa lezake $X^{o}$ kategoriako elementu bat espezifikatzaile gunera mugitzen delako proposamenak Kateen Uniformitatearen Baldintza (Uniformity Condition on Chains, cf. Chomsky 1995: 253) urratzen duela. Hala ere, programa minimalistaren azken garapenetako zenbait proposamenen arabera, zalantzazkoa da buru- eta sintagma-mugimenduaren arteko bereizketari eutsi behar zaion, batik bat mugimendu oro tasun-balioztatzea + bat egitea eragiketetara murrizten dela pentsatzen badugu (ik. batez ere Matushansky 2006). Izan ere, Matushanskyk proposatzen duenaren ildotik, sintagma-mugimenduan nahiz buru-mugimenduan tasunak balioztatzeko mugitzen da elementu bat espezifikatzailera, baina ondoren, buru-mugimenduan soilik gertatzen den 'bat egite morfologikoa' (morphological merger) gertatzen da mugitutako buruaren eta helburua den buruaren artean. Mugimendu hau morfologiaren atalean gertatuko litzateke. Ikuspegi honetatik, egin aditzaren mugimenduak azalduko luke zergatik ezin daitekeen ezer agertu fokalizatutako aditzaren eta egin-en artean.

Azterbide hau zuzena delakoan, hurrengo atalean bikoizketa egituretarako analisi bera heda daitekeela azaltzen saiatuko naiz.

\section{Bikoizketa egiturak}

Hirugarren atalean aipatu denez, mendebaleko hizkeretan aditz trinkoek adierazten duten ekintza edo gertaera fokalizatu nahi dugunean, jatorrizko gunean egin aditz arinaren ordez, aditz trinkoa bera ageri da, errepikaturik, eta foku gunean aditz trinkoari dagokion aditz partizipioa.

(17) Gau guztian, nundik nora eztakidala ta neure gerizea baino beste lagun bage, ibili nabil (Azkue 1893, 91 or.) $)^{22}$

Egin egituretarako erabili dudan azterbidea egitura hauetara hedatzea proposatzen dut, alegia, era trinkoan jokatzen den aditza fokua denean, foku gunera mugitzen da, eta, ondorioz, aditz hauei dagokien aspektu [+puntukaria] balioztatuko duen adizki jokatu betegarria txertatzen da: kasu honetan aditzaren kopia jokatua, egin ezin baita era trinkoan jokatu aditz betegarri gisa erabiltzen denean: ${ }^{23} 24$

(18) $\left[_{\text {FokS }} A_{\text {trink }} \cdots\left[_{\text {InflS }}\left[{ }_{A S} A_{\text {jok }}\right]\right.\right.$ Infl] $]$

Beste hizkuntza askotan ere aurkitzen ditugu aditzaren bikoizketa kasuak. Ezaguna da hainbat

22. Aipagarria da Azkuek berak ez diela egitura bikoiztu hauei foku irakurketarik esleitzen. Izan ere, aditz trinkoen "orainaldi jarraitua" adierazteko modua dela besterik ez du esaten (Azkue 1923: II: 527 \$760). Hala ere, (17)-ko adibidean agerian da egiturak balio enfatikoa edo indargarria duela.

23. Besterik da egin laguntzaile modura erabiltzen den (eta erabili izan) den kasuan. Hauetan, jakina, egin era jokatuan ager daiteke.

24. Hala ere, azterketa gehiago eskatzen duen diferentziarik bada bi egituren artean: egin egituretako foku mugimenduak perpaus bat baino gehiago zeharka dezakeen bitartean, badirudi bikoizketa egituretakoa perpaus bakarrera mugatzen dela, datuak zalantzazkoak badira ere (X. Artiagoitia, k.p.):

(i) [saldu esan didate [egingo dutela baserria] ]

(ii)?/??[joan esaten dute [doala ] ]

25. Hebraieraz ere aditz-bikoizketa aurkitzen dugu, baina Landauk $(2006,2007)$ ohartarazten duenez, topikalizazio testuinguruetan erabiltzen ohi da. Beste alde batetik Jouitteau-k (2007, prentsan) proposatzen du Bretoieraz aditza ez dela bikoizten topiko-fokuekin lotutako arrazoiengatik, baizik eta exkorporazio bidez, aditz jokatua lehen posizioan agertzeko debekutik babesteko. 
hizkuntzak aditza bikoizteko estrategia erabiltzen dutela aditza fokua dela markatzeko, hala nola kwa eta bantu familietan (Aboh 2007), Haitiko kreoleran eta krueran (Koopman 1984, Manfredi 1993), errusieraz (Abels 2001), yiddishean (Davis \& Prince 1986) eta koreeran (Jo 2003). ${ }^{25}$ Honen erakusgarri, hona hemen adibide bat:

(19) Đà \%w Y tì dà àvlántò [Gungbe (Kwa hizkuntza)]

cook Foc Yeti cook plantain

'Yetik banana PRESTATU zuen bazkaltzeko'

Aipatu ditugun hizkuntzen aldean, euskaraz aditz-fokalizazioan aurkitzen dugun aditza bikoizteko estrategia aditz trinkoei mugatzen zaie. Ez da hala gertatzen, ondoren ikusiko dugunez, topikalizazio testuinguruetan.

\section{Alternantziaren berri eman nahian. Hurbilketa bat}

Egin-en eta aditzaren bikoizketaren erabileran euskalkietan aurkitzen dugun aldakortasuna fokalizazio testuinguruetan azaltzen da; ez, aitzitik, aditzaren topikalizazioan.

(20) a. (saiakera-liburuak) irakurri, gutxi egiten dute gazte euskaldunek

b. Jakin, ondo daki horrek zer egiten duen

Goiko adibideen tankerakoak ehunka sor ditzakegu, edozein delarik darabilgun euskalkia. Hartara, testuinguru fokalizatuetan egin erabiltzen ez duten hizkeretan egin ageri da aditza (edo AS) topikoa denean, eta aditz trinkoen kasuan, aditza bikoizten da. Nola azal daiteke jokabide desberdin hau? Posibilitate bat da pentsatzea ekialdeko hizkeretan aditzak, fokua denean, nahitaez eraman behar dituela aspektu-tasunak berarekin goranzko mugidan. Hau da, aditzak aspektua 'garraiatzen' du (pied-piping) foku gunera mugitzen denean. Garraiatzearen arrazoia ez da argia; beharbada $[A+a s p]-e k$ gune diferenteetan egiten dute bat ekialdeko euskalkietan eta besteetan: lehenengoetan morfologian, mugitu aurretik, eta beste hizkeretan sintaxian. Horregatik ez da egin txertatzen lehenengoetan. Ikerketaren puntu honetan ideia hau azalpen baterako hurbilketa bat besterik ez da, eta zalantzarik gabe azterketa gehiago eskatzen du. Baina ideia bezala azter daitekeela iruditzen zaigu. ${ }^{26}$

Itzul gaitezen aditzaren topikalizazio testuingurura. Kontestu honetan egin euskalki guztietan erabiltzen da. Azalpen bateratua eman nahi badiogu egin-en agerpenari aditzaren fokalizazio zein topikalizazioetan, azaldu beharra dago zergatik agertzen den egin ekialdeko hizkeretan. Eman dezagun topikalizazioetan aditza ez dela mugitzen proposatzen dugula; aitzitik, ezkerraldean sortzen da, eta perpaus barruko egonguneari lotzen zaio egin proformaren bitartez. ${ }^{27}$ Proposamen

26. Izan ere, pied-piping gertakaria dela eta, zenbait hizkuntza erromantzetarako hainbatek proposatu dute aditz laguntzaile modalak zein aspektualak nahitaez garraiatzen dutela infinitiboa berarekin, laguntzailea eremu funtzionalera mugitzen denean (cf. Bok-Bennema 2001). Ikus baita ere Ndayiragije (2000), non proposatzen den tasun formalez gain, [hizkia] bezalako tasun fonologikoek ere mugimendua erakar dezaketela aditz-bikoizketa egituretan.

27. Elordieta (agertzeko) lanean ideia hau agertzen da aurreneko aldiz. Oraingo lan honetan aditz topikalizazioan mugimendurik ez dela gertatzen erakusten duten hainbat argudio aurkezten ditut, ideia gehiago garatuz. 
honetan aditz betegarriak aspektu-tasunen balioztatze lanak egiten ditu, fokalizazioetan bezala, baina, garrantzitsuki, aditza ez da mugitu. Honek azalduko luke zergatik ageri den egin aditztopikalizazioetan baina ez fokalizazioetan. Ikuspegi honetatik, egin aditzaren proforma da, aditz lexikoa falta denean egituran txertatzen dena aspektu-tasunak balioztatzeko. Horregatik, aditzaren ekintza fokua denean, mendebaleko eta erdialdeko hizkeretan egin txertatzen da A [Esp, FokS]-ra mugitzen delako, baina ez ekialdeko hizkeretan, foku gunera mugitzen dena [A+asp] delako.

Ondoren proposamen honen aldeko argudio batzuk aurkeztuko ditut; lehendabizi aditzaren topikalizazioan aditza ez dela mugitzen pentsarazten diguten bi argudio, eta bigarrenik egin aditz betegarria agertzea espero genukeen bi kontestu berri aztertuko ditugu.

\section{Zenbait ebidentzia}

\subsection{Irla-efekturik ez topikalizazioetan}

Aditzaren edo AS-ren topikalizazioak ez du irla efekturik erakusten:

(21) a. Lan egin, zure gurasoek [gurekin egingo duzun] uste osoa dute.

b. *gurekin, zure gurasoek [lan egingo duzun] uste osoa dute.

(21b)-k emaitza okerragoak ematen ditu (21a)-k baino. Kontraste honen berri erraz eman daiteke (2la)-n mugimendurik gertatu ez dela proposatzen badugu, baina (21b)-n bai.

\subsection{Komunztadura}

DetS-ren topikalizazioak ez du eraginik komunztaduran, (22a)-k erakusten duenez. Era berean, fokalizazio testuinguruetan egin-ek objektuarekiko komunztadurari eusten dio (22b). Aitzitik, topikalizatutako AS-k objektu plurala badu, aditz laguntzaileak ez du objektuarekin komunztatzen, baizik eta singularrari dagokion komunztadura erakusten du (22c):

(22) a. Kotxeak, nik dakidala, gutxiegi saldu dira hilabete honetan

b. Kotxeak saldu egin dira gutxiegi hilabete honetan

c. Kotxeak saldu, nik dakidala, gutxiegi egin da hilabete honetan $\quad(*$ dira $)$

Izan ere, gaztelaniaz antzeko datuak aurkitzen ditugu, lo klitikoak singularrean komunztatzen baitu, ez pluralean:

(23) leer libros, no lo/*los hacen muy a menudo, la verdad

Datu hauek azalpen bat baino gehiago izan badezakete ere, gutxienez gure hipotesiarekin bat egiten dute: AS ezkerrean bertan sortua bada, eta ez mugimenduaren ondorioz, espero izatekoa da aditz laguntzaileak besterik ezean ezartzen den komunztadura agertzea, alegia, singularrari dagokiona.

\subsection{Elipsia}

Gure hipotesia zuzena bada, bada beste testuinguru bat non egin agertuko dela espero dugun: AS-ren elipsi kasuetan hain zuzen. (24)-ko adibideak erakusten duenez, AS-ren elipsi-egituretan aditz lexikoa ez da ahoskatzen, baina denbora- eta aspektu-tasunak agerian egon behar dira, ez baitute bat egiten aitzindaria den lehen perpauseko denbora-aspektu tasunekin ([+burutua, -oraina] 
lehen perpausean, [-burutua, +oraina] bigarrenean). Kontestu hau aproposa da egin proformaren txertaketarako, eta iragarpena bete egiten da:

(24) Ana uretara sartu zen, baina nik gaur ez dut egingo [AS

\subsection{Ezeztapena}

Ezeztapeneko datuek egin-en jokabidea ulertzeko bidea ematen dute, (25b1) eta (25b2)-ren arteko kontrasteak aditzera ematen duenez:

(25) a. Entzun dut Jonek ez dituela lortu kontzerturako sarrerak

b1. Nola ezetz? Erosi ez ditu egin, baina lagun batek oparitu dizkio

b2.?? Nola ezetz? Jonek ez ditu erosi egin sarrerak, oparitu egin dizkiote

Hau da, egin zilegi da aditz nagusia ezeztapenaren aurretik ageri bada, baina emaitza okerra da ezeztapenaren ondoren ageri bada. Ezeztapenaren kokagunea euskararen perpaus egituran 'goian' dagoela onartzen badugu, ohi den bezala (ikus Laka 1990, Ortiz de Urbina 1995, Haddican 2004), horrek esan nahi du (25b1)-en aditza ez dagoela bere kokagune kanonikoan, baizik eta gorago (dela topikoan, dela fokuan), eta hortaz, pentsa daiteke egin kokagune kanonikoan ageri dela. Aldiz, (25b2)-n ez dago ebidentziarik A bere posiziotik kanpo dagoela pentsatzeko. Mugitu ez bada, ez dago arrazoirik egin txertatzeko; horrek azalduko luke zergatik baztertzen dugun (25b2).

\section{Laburbilduz}

Lan honetan aditza fokalizatzeko aldakortasun dialektala erakusten duten bi estrategia aztertu ditugu:

1) aditz trinkoen bikoizketa

2) egin-en txertaketa

Mekanismo bien banaketa dialektala berdina ez den arren, modu beretsuan azter daitezkeela erakusten saiatu naiz, Rebuschik (1983) aspaldian proposatu zuen ideia garatuz. Zehazki, bai egin bai aditz 'bikoiztuak' aspektu-tasunak balioztatzeko txertatzen dira, aditz lexikala bere ohiko egongunean ageri ez den kontestuetan. Testuinguru horien bi adibide garbi aurkitzen ditugu aditzak adierazten duen ekintza/gertaera fokua denean eta aditza topikoa denean. Lehen kasuan aditza foku gunera mugitzen dela proposatu dugu, eta topikalizazioan, aldiz, ezkerraldean bertan sortzen dela. Hori frogatzeko, bi argudio aurkeztu ditugu: topikalizazioetan irla-efekturik ez dagoela, eta aditz laguntzaileak topikalizatu den AS-ren objektuarekin ez duela objektu-komunztaduratik erakusten. Bestalde, AS-ren elipsiko datuek bat egiten dute egin-en gainean egiten dugun proposamenarekin, alegia, aditza ez, baina denboraaspektu tasunak agerian egon behar direnean egin txertatuko dela.

\section{Aipamenak}

Abels, K. 2001. "The predicate cleft construction in Russian". Formal Approaches to Slavic Linguistics (FASL) 9:1-18. Ann Arbor: Michigan Slavic Publications.

Aboh, E.O. 2007. "Leftward Focus versus Rightward Focus: the Kwa-Bantu Conspiracy", SOAS WPiL 15:81-104.

Altube, S. 1929. Erderismos. Bermeo [2. argitaraldia, Bilbao, 1975].

Arejita, A. 1984. Euskal Joskera. Bilbao: Labayru Ikastegia. 
Arejita, A. 1980. "Aditzaren galdegai funtzinoaz", Euskera XXV, 355-369. Bilbao: Euskaltzaindia.

Artiagoitia, X. 1995. Verbal Projections in Basque and Minimal Structure. ASJU-ren Gehigarriak XXXVI, EHU-Gipuzkoako Foru Aldundia, Donostia.

Azkue, R.M. 1893. Lenengo irakurgaia. Bein da betiko. Imprenta de la Casa de Misericordia.

Azkue, R. M. 1923. Morfología Vasca. II. Liburukia. Edit. La Gran Enciclopedia Vasca.§ 760, 527.

Bok-Bennema, R., B. De Jonge, B. Kampers-Mahne, Mohlendijk (arg.). 2001. Adverbial Modification. Groningen: Rodopi.

Chomsky, N. 1995. The Minimalist Program. Cambridge: MIT Press.

Davis, L. J. \& E. F. Prince. 1986. Yiddish verb-topicalization and the notion "lexical integrity". Chicago Linguistic Society (CLS) 22:90-97. Chicago: University of Chicago.

Elordieta, A. 2001. Verb Movement and Constituent Permutation in Basque. 47 LOT Dissertation Series, Utrecht.

Elordieta, A. (agertzeko). "Foku-mintzagaien gainean ohar batzuk: azentu nagusia aditzak daramanean". Gorrotxategi, J., J. A. Lakarra eta B. Urgell (arg.) Koldo Mitxelena Katedraren II. Biltzarraren agiriak.

Etxepare, R. eta J. Ortiz de Urbina. 2003. "Focalization". J. I. Hualde \& J. Ortiz de Urbina (arg.) A Grammar of Basque. Berlin: Mouton de Gruyter, 460-516.

Euskaltzaindia. 1985. Euskal Gramatika. Lehen Urratsak-I. Bilbo: Euskaltzaindia.

Euskaltzaindia. 1993. Euskal Gramatika Laburra: Perpaus Bakuna. Bilbo: Euskaltzaindia.

Haddican, B. 2004. "Sentence polarity and word order in Basque". The Linguistic Review21, 87-124.

Haddican, B. 2005. "On egin: do-support and verbal focus in Central and Western Basque". Proceedings of the 29th Penn Linguistics Colloquium.

Haddican, B. 2007. "On egin: do-support and verbal focus in Central and Western Basque". Natural Language and Linguistic Theory 25:4, 735-764.

Irurtzun, A. eta M. Duguine. 2008. "The Left Periphery in Navarro-Labourdin: marked foci, whconstructions and cleft sentences". Paper presented at Licensing Conditions at the Interfaces. Donostia, 2008/6/23-24.

Jo, J.-M. 2003. "Variations in predicate cleft constructions in Korean: Epiphenomena at the Syntax-PF interface." Paper presented at the 10th Harvard International Symposium on Korean Linguistics, Harvard University.

Jouitteau, M. 2007. "The Brythonic reconciliation from V1 to generalized V2". The Linguistic Variation Yearbook, Craenenbroek \& Rooryck (eds.), Netherlands. lingBuzz/000681.

Jouitteau, M. prentsan, 'Verb second as morphological obligatory exponence : Breton verbal reiteration', In Aboh and Zribi-Hertz (eds.), Morphosyntax of reiteration.

Koopman, H. 1984. The syntax of verbs: From verb movement rules in the Kru languages to Universal Grammar. Dordrecht: Foris.

Lafitte, P. 1944. Grammaire Basque (navarro-labourdin littéraire). Ed. Revue et corrigée, 1978. Donostia : Elkar.

Laka, I. 1990. On the Nature of Functional Categories and Projections. Doktorego tesia, MIT.

Landau, I. 2006. "Chain resolution in Hebrew VP-fronting". Syntax 9:1, 32-66. 
Landau, I. 2007. "Constraints on partial VP-fronting". Syntax 10:2, 127-164.

Manfredi, V. 1993. "Verb focus in the typology of Kwa/Kru and Haitian". In F. Byme \& D. Winford (arg.) Focus and grammatical relations in Creole languages, Amsterdam/Philadelphia: John Benjamins, 3-51.

Matushansky, O. 2006. "Head movement in linguistic theory". LI 37:1, 69-109.

Mitxelena, K. 1981. "Galdegaia eta mintzagaia euskaraz". Euskal linguistika eta Literatura, Deustuko Unibertsitatea. 57-81.

Mitxelena, K., I. Sarasola. 1984-2005. Orotariko Euskal Hiztegia. Bilbao: Mensajero y Desclée de Broweer.

Mounole, C. 2008. "Perifrasi zaharra mendebalde eta erdialdeko hizkeretan: aldaerak eta aldaketak diakronian". Aldaketak, aldaerak, bariazioak euskaran eta euskal testugintzan Nazioarteko Mintegian aurkeztutako komunikazioa. Baiona, 2008/12/12-13.

Ndayiragije, J. 2000. "Strengthening PF". Linguistic Inquiry 31:3, 485-512.

Ortiz de Urbina, J. 1989. Parameters in the Grammar of Basque, Dordrecht: Foris.

Ortiz de Urbina, J. 1994. "Verb initial patterns in Basque and Breton". Lingua, 125-153.

Ortiz de Urbina, J. 1995. "Residual Verb Second and Verb First in Basque". In K. Kiss (arg.) Discourse configurational languages, 99-121.

Osa, E. 1990. Euskararen hitzordena komunikazio zereginaren arauera. Doktorego tesia,

UPV/EHU. Leioa: EHUko Argitalpen Zerbitzua.

Oyharçabal, B. 1984. "Ba- baiezkoa aurrizkia". Euskera XXIX, 351-371.

Rebuschi, G. 1983a. "Anglais do et basque egin: analyse constrastive ». 23rd Meeting of the Société des Anglicistes de l'Enseignement Superiéur (Rheims)-en aurkeztutako komunikazioa.

Rebuschi, G. 1983b. "A Note on Focalization in Basque”. ASJU 4:2, 29-42. [Rebuschi, G. (1997) Essais de linguistique basque liburuan berrargitaratua. ASJU-ren Gehigarriak XXXV, EHU-Gipuzkoako Foru Aldundia, Donostia, 31-41.]

Zuazo, K. 1998. "Euskalkiak gaur". Fontes Linguae Vasconum 30. 191-233.

Zuazo, K. 2003. Euskalkiak. Herriaren lekukoak. Donostia: Elkar.

Zuazo, K. 2008. Euskalkiak. Euskararen dialektoak. Donostia: Elkar. 